\title{
Economic Development Analysis of Three Famous Tourist Destinations in Purbalingga
}

\author{
Agus Arifin ${ }^{1, *}$, Rakhmat Priyono ${ }^{2}$
}

\author{
${ }^{1,2}$ Department of Economics and Development Studies, Faculty of Economics and Business, Jenderal Soedirman University, \\ Indonesia \\ ${ }^{*}$ Corresponding author. Email: arifinie@gmail.com
}

\begin{abstract}
This research focuses on economics tourism studies which analyse the economic development of three famous tourist destinations in Purbalingga Regency, i.e. Owabong Waterpark, Sanggaluri Reptile Park, and Purbasari Riverworld. The objectives of this research are (1) to measure willingness to pay of tourist destinations and (2) to analyse factors affecting willingness to pay of each tourist destination. This research uses travel cost method and multiple regression technique with incidental sampling technique for collecting primary data and supported by secondary ones from related institutions. The research findings are (1) willingness to pay of each destination is still at recommended price/ticket which ranges IDR25,00035,000 for Owabong Waterpark, IDR15,000-20,000 for Sanggaluri Park, and IDR20,000-25,000 for Purbasari Riverworld; (2) the major determinant factors of willingness to pay of those three destinations are travel costs, visitor income, and visitor perceptions.
\end{abstract}

Keywords: willingness to pay, travel cost, tickets, tourist destination, waterpark

\section{INTRODUCTION}

Indonesia is one of the largest archipelagic countries with various ethnic groups, ethnicities, and different races. The tourism sector is one of the potential sectors in order to improve the economy of a country, such as increasing regional and state revenues, contributing to national development, increasing job opportunities, and improving people's living standards [1]. Indonesia is a developing country that has great potential in the tourism sector. Indonesia's tourism potential is able to compete with other countries in the tourism industry. There are three aspects of Indonesia's tourism advantages, i.e. natural tourism (60 percent), heritage tourism (35 percent), and artificial tourism (5 percent) such as culinary, shopping, and others [1].

Ecotourism is a tourism based on nature by including aspects of education and interpretation of the natural environment and culture of the community with ecological sustainability management [2][3][4]. Ecotourism can be the main alternative for the community on recreational needs, because recreation has become a human need to refresh the mind and condition of the body after undergoing the routine of daily life. Ecotourism has become a trend and demand thus creating opportunities to attract more tourists [5].

The contribution of the Indonesian tourism sector to the national economic sector has continued to increase from year to year [6]. This contribution can be seen from the number of visits by foreign and domestic tourists, foreign exchange earnings, and gross domestic product (GDP), which can be seen in Table 1 .

Table 1. Indonesia Tourism Contribution to GDP, 2015-2018

\begin{tabular}{|c|c|c|c|c|}
\hline Year & 2015 & 2016 & 2017 & 2018 \\
\hline $\begin{array}{l}\text { Foreign } \\
\text { visitors } \\
\text { (thousands of } \\
\text { people) }\end{array}$ & $10,230.8$ & $11,519.3$ & $14,039.8$ & $15,810.3$ \\
\hline Change (\%) & - & 12.6 & 21.9 & 12.6 \\
\hline $\begin{array}{l}\text { Domestic } \\
\text { visitors } \\
\text { (person) }\end{array}$ & $256,419.0$ & $264,337.5$ & 270.822 .0 & $303,403.9$ \\
\hline Change (\%) & - & 3.1 & 2.5 & 12.0 \\
\hline $\begin{array}{l}\text { Foreign } \\
\text { exchange } \\
\text { revenue (\$US } \\
\text { billion) }\end{array}$ & 10,761 & 11,206 & 13,139 & 16,426 \\
\hline Change (\%) & - & 4.1 & 17.2 & 25.0 \\
\hline $\begin{array}{l}\text { Contribution } \\
\text { to GDP (\%) }\end{array}$ & 4.1 & 4,3 & 4,1 & 6 \\
\hline
\end{tabular}

Source: Statistics Indonesia, 2019

Therefore, the tourism is promising sector to be developed and can become a mainstay in the future. Moreover, in the tourism sector development, the strategy to increase visitor number, indirectly, can also support Local Own-Source Revenue (PAD). It can be seen through ticket 
sales and the growth of other economic fields due to the increase in visitors. In Table 2 the number of visitors in Central Java (2013-2020) can be observed.

Table 2. The Number of Visitors in Central Java Province, 2013-2020

\begin{tabular}{lrrrr}
\hline \multirow{2}{*}{ Year } & \multicolumn{4}{c}{ Visitors } \\
\cline { 2 - 5 } (person) & $\begin{array}{c}\text { Foreign } \\
\text { (person) }\end{array}$ & \multicolumn{1}{c}{$\%$} \\
\hline 2013 & 388,143 & - & $29,430,609$ & - \\
2014 & 419,584 & 8.10 & $29,852,095$ & 1.43 \\
2015 & 421,191 & 0.38 & $33,030,843$ & 10.65 \\
2016 & 578,924 & 37.45 & $36,899,776$ & 11.71 \\
2017 & 782,107 & 35.10 & $40,118,470$ & 8.72 \\
2018 & 677,168 & -13.42 & $49,943,607$ & 24.49 \\
2019 & 691,699 & 2.15 & $57,900,863$ & 15.93 \\
2020 & 78,290 & -88.68 & $22,629,085$ & -60.92 \\
\hline
\end{tabular}

Source: Regional Youth, Sport, and Tourism Service of Central Java Province, 2021

The number of foreign and domestic visitors in Central Java Province from 2013 to 2019 showed a fluctuating positive increase, apart from a sharp decline in 2017-2018 at foreign visit due to several factors (seasonal, natural disasters, and policies) and in 2020 at foreign and domestic visits due to the covid-19 pandemic. The relatively positive increase in visits, before pandemic, indicates the positive impact on the development of tourism sector in Central Java Province. Purbalingga is the regency with the fourth rank achievement in Central Java Province in terms of tourism revenue, where there are three famous tourist attractions close to each other, namely Owabong Waterpark, Sanggaluri Reptile Park, and Purbasari Riverworld. Those three destinations can contribute to the Purbalingga Local OwnSource Revenue (PAD) of around IDR 3-4 billion each year [7].

Hence, it is interesting and necessary to conduct an indepth study to measure willingness to pay and analyse its determinant factors at those three tourist destinations. Willingness to pay (WTP) is as the main variable and there are some independent variables that can be explored such as travel distance, travel cost, visitor income, visitor age, etc.

\section{LITERATURE REVIEW}

The economic value of natural resources is generally non-market or non-tradable then it needs certain technique to measure the value [8]. One of recommended technique should be the Travel Cost Method (TCM). It uses two method, i.e. Zonal Travel Cost Method (regional zones based-approach) and Individual Travel Cost Method (individual travel costs based-approach) [9].

In progress, the Individual Travel Cost Method (ITCM) is commonly used because it can include the information about social characteristics such us income, age, gender, etc.
By using Zonal Travel Cost Method (ZTCM) those information can't be captured [10][11]. Travel Cost Method (TCM) uses the willingness to pay (WTP) approach that analyses how much the economic value is willing to be paid by those who receive or take advantage of an economic activity. In other words, WTP encourages information about the ability of individuals or communities to pay certain amount of money to develop some conditions to achieve the desired environtmental service standard [12][13].

Here are several researches using TCM and WTP. Bhatt and Bhat (2016) used TCM to estimate the value of recreational use of Dachigam National Park [14]. Some variables were analysed consists of visitor number, visitor income, travel cost, travel distance, age, gender, and visitor ecucation. The finding stated that the significant variables affecting visitor number are travel distance, travel cost, income, and education. Haider et al. (2017) studied willingness to pay (WTP) to value of recreation and build some facilities to attract tourists in Bangladesh, i.e. Shat Mozaffar Park, Niribili, Gumbuj Mosque, and Chandramahal Eco-park [15]. By using TCM and Contingency Value Method (CVM) some variables can be explored, such as travel costs, travel time, travel duration, travel distance, vehicles used, etc. The result stated that travel cost, travel distance, and age effect negatively on visit probability.

Other previous research by Cheung \& Jim (2014) concluded that higher income and education, and also the younger visitors ready to pay more for enjoying conservation views [16]. As well, El-Bekkay et al. (2013) analysed the recreational value of Massa River Estuary site using CVM and TCM [17]. This study used visit number as dependent variable and travel distance, age, travel time, number of children, travel cost, visitor income, and WTP as independent variables. Some findings are the estimated consumer surplus is at USD65.36 and willingness to pay per visitor is around USD6.20; the improvement of facilities and conservation should pay attention the opportunities and potentials that exist as a promising recreational attraction. Moreover, Terry, Mukti, and Sunaryati (2020) also concluded that WTP can be affected by visitor education and age, environmental cleanliness, visitor convenience and satisfaction [18]. Other findings are the suggestion to increase tourist attractions should be good facilities, easy access, and fulfilled satisfaction.

\section{RESEARCH METHOD}

This research needs data from respondents by using incidental sampling where each visitor can be as a respondent as long as suitable with the criteria [19]. Using Lemeshow formula (1997) the number of sample can be determined [20].

$$
\begin{aligned}
& \mathrm{n}=\frac{p(1-p)\left(\frac{Z \alpha}{2}\right)^{2}}{D^{2}} \\
& \mathrm{n}=\frac{0,5(1-0,5)\left(1,96^{2}\right)}{0,1^{2}} \\
& \mathrm{n}=96 \text { persons }
\end{aligned}
$$


where:

$\mathrm{n}=$ sample size

$\mathrm{Z}=$ standard value of distribution at $\alpha=5 \%$, i.e. 1.96

$\mathrm{p}=$ outcome prevalence, because data have not been obtained, the maximum estimate is used, i.e. 0.5

$\mathrm{D}=$ accuracy level of 0.1

\subsection{Measuring Willingness to Pay (WTP)}

The contingency value method (CVM) is used to analyze Willingness to Pay (WTP) of visitors for the benefits they get from enjoying a tourist attraction, in relation to improving the environmental conditions of the tourist attraction. The different preferences of individual tourists for the increase or decrease in the value of the use and management of natural resources will cause the WTP value of each tourist to vary.

Here, some approaches to measure WTP for the representation of increase or decrease in environmental conditions are:

a. Conduct survey to determine the level of willingness to pay of each people in order to achieve better environmental quality.

b. Calculating the cost that people are willing to pay for reducing the negative impact on the environment due to a development activity.

c. Calculating the reduction/increase in the price of a good due to decreasing/increasing environmental quality.

\subsection{Analyzing Determinant Variables of Willingness to Pay (WTP)}

By using TCM and CVM, all of data were entered into the equation that analyzes the determinants of WTP [21][22].. The equation can be written as:

$$
\begin{aligned}
\operatorname{Ln} Y_{i}= & \beta_{0}+\beta_{1} \operatorname{Ln} X_{1 i}+\beta_{2} \operatorname{Ln} X_{2 i}+\beta_{3} \operatorname{Ln} X_{3 i}+\beta_{4} \operatorname{Ln} X_{4 i}+ \\
& \beta_{5} \operatorname{Ln} X_{5 i}+\mathrm{e}
\end{aligned}
$$

where:

$Y_{\mathrm{i}}=$ Willingness to Pay /WTP (IDR)

$X_{1}=$ travel cost (IDR)

$X_{2}=$ Visitor age (year)

$X_{3}=$ travel distance $(\mathrm{km})$

$X_{4}=$ visitor income (IDR)

$X_{5}=$ visitor perceptions of facilities and infrastructure

$i=$ cross section

$\mathrm{e}=$ error terms

$\beta_{1,2, \ldots, 5}=$ regression coefficient

$\beta_{0}=$ constant

The equation was processed by multiple linear regression (MLR) to analyze the determinant variables of WTP. According to the rule, firstly, classical assumptions test must be done which consists of multicollinearity, heteroscedasticity, and autocorrelation tests. After passing all tests then model is already to be interpreted by using statistical test, i.e. the $\mathrm{R}^{2}$ test, $\mathrm{F}$ test, and t test [19].

\section{RESULT AND DISCUSSION}

\subsection{Result of Measuring Willingness to Pay (WTP)}

This analysis will measure how much the visitors are willing to pay a certain amount (rupiah) to be used for maintenance, repair and development, both in quality and quantity, in relation to the various facilities and rides available in locations. The method used is CVM that is the technique of measuring Willingness to Pay (WTP).

The first step is asking visitors the bidding value from increasing entrance tickets by $15-20$ percent but with information that some facilities will be improved and some new rides will be provided. Here is the list of ticket price as bidding value for each tourist destination: IDR25,000-35,000 for Owabong Waterpark, IDR15,000-20,000 for Sanggaluri Reptile Park, and IDR20,000-25,000 for Purbasari Riverworld. For those price changes, respondent was asked to give his/her opinion by choosing the criteria of strongly agree (5), agree (4), neutral (3), disagree (2), strongly disagree (1). The results of the study are shown in Table 3 until Table 5 below.

Table 3. Willingness to Pay (WTP) of Owabong Visitors:

\begin{tabular}{|c|c|c|c|c|c|c|c|}
\hline \multirow{2}{*}{ No } & \multirow{2}{*}{ Visitor Income } & \multicolumn{6}{|c|}{ Choice } \\
\hline & & 5 & 4 & 3 & 2 & 1 & Total \\
\hline 1 & $<1.000 .000$ & 1 & 1 & 0 & 0 & 1 & 3 \\
\hline 2 & $\begin{array}{l}1.000 .000- \\
2.000 .000\end{array}$ & 4 & 6 & 2 & 2 & 1 & 15 \\
\hline 3 & $\begin{array}{l}2.000 .000- \\
3.000 .000\end{array}$ & 4 & 4 & 2 & 2 & 1 & 13 \\
\hline 4 & $\begin{array}{l}3.000 .000- \\
4.000 .000\end{array}$ & 1 & 2 & 1 & 1 & 1 & 6 \\
\hline 5 & $>4.000 .000$ & 1 & 1 & 1 & 0 & 0 & 3 \\
\hline & TOTAL & 11 & 14 & 6 & 5 & 4 & 40 \\
\hline & $\%$ & 27.5 & 35 & 15 & 12.5 & 10 & 100 \\
\hline
\end{tabular}
Bid Value IDR25,000-35,000

Source: Primary data, processed

The result displaying at Table 3 shows the opinion of respondents, i.e. 27.5 percent strongly agree, 35 percent agree, 15 percent are neutral, 12.5 percent disagree, and 10 percent strongly disagree. In other words, the visitors who agreed (strongly agree and agree) were 62.5 percent, while those who disagreed (disagree and strongly disagree) were 22.5 percent, and only 15 percent were neutral. Thus, the entrance ticket can be proposed at range IDR25,000-35,000. 
Table 4. Willingness to Pay (WTP) of Sanggaluri Visitors: Bid Value IDR15,000-20,000

\begin{tabular}{|c|c|c|c|c|c|c|c|}
\hline \multirow{2}{*}{ No } & \multirow{2}{*}{ Visitor Income } & \multicolumn{6}{|c|}{ Choice } \\
\hline & & 5 & 4 & 3 & 2 & 1 & Total \\
\hline 1 & $<1.000 .000$ & 1 & 1 & 0 & 1 & 1 & 4 \\
\hline 2 & $\begin{array}{l}1.000 .000- \\
2.000 .000\end{array}$ & 3 & 4 & 1 & 1 & 1 & 10 \\
\hline 3 & $\begin{array}{l}2.000 .000- \\
3.000 .000\end{array}$ & 2 & 2 & 1 & 1 & 1 & 7 \\
\hline 4 & $\begin{array}{l}3.000 .000- \\
4.000 .000\end{array}$ & 1 & 1 & 1 & 2 & 1 & 6 \\
\hline 5 & $>4.000 .000$ & 1 & 1 & 1 & 0 & 0 & 3 \\
\hline & TOTAL & 8 & 9 & 4 & 5 & 4 & 30 \\
\hline & $\%$ & 26.7 & 30 & 13.3 & 16.7 & 13.3 & 100 \\
\hline
\end{tabular}

Source: Primary data, processed

From Table 4 it can be seen that the opinion of respondents, i.e. 26.7 percent strongly agree, 30 percent agree, 13.3 percent are neutral, 16.7 percent disagree, and 13.3 percent strongly disagree. In other words, the visitors who agreed (strongly agree and agree) were 56.7 percent, while those who disagreed (disagree and strongly disagree) were 30 percent, and only 13.3 percent were neutral. Therefore, it can be concluded that the entrance ticket should be at range IDR15,000-20,000.

Table 5. Willingness to Pay (WTP) of Purbasari Visitors: Bid Value (IDR20,000-25,000)

\begin{tabular}{|c|c|c|c|c|c|c|c|}
\hline \multirow{2}{*}{ No } & \multirow{2}{*}{ Visitor Income } & \multicolumn{6}{|c|}{ Choice } \\
\hline & & 5 & 4 & 3 & 2 & 1 & Total \\
\hline 1 & $<1.000 .000$ & 1 & 0 & 0 & 1 & 1 & 3 \\
\hline 2 & $\begin{array}{l}1.000 .000- \\
2.000 .000\end{array}$ & 2 & 4 & 1 & 2 & 1 & 10 \\
\hline 3 & $\begin{array}{l}2.000 .000- \\
3.000 .000\end{array}$ & 3 & 2 & 1 & 2 & 1 & 9 \\
\hline 4 & $\begin{array}{l}3.000 .000- \\
4.000 .000\end{array}$ & 1 & 2 & 1 & 2 & 1 & 7 \\
\hline 5 & $>4.000 .000$ & 0 & 1 & 0 & 0 & 0 & 1 \\
\hline & TOTAL & 7 & 9 & 3 & 7 & 4 & 30 \\
\hline & $\%$ & 23.3 & 30 & 10 & 23.3 & 13.3 & 100 \\
\hline
\end{tabular}

Source: Primary data, processed

Table 5 shows the opinion of respondents, i.e. 23.3 percent strongly agree, 30 percent agree, 10 percent are neutral, 23.3 percent disagree, and 13.3 percent strongly disagree. In other words, the visitors who agreed (strongly agree and agree) were 53.3 percent, while those who disagreed (disagree and strongly disagree) were 36.7 percent, and only 10 percent were neutral. Hence, the result concludes that the entrance ticket should be at range IDR15,000-20,000.

This finding supports the previous research by Pascoe et al. (2014) that the costs of managing the tourist attraction or reserves tend to fall mostly with the domestic authorities, then, consequently, there is a strong suggestion to increase the contributions of visitors in particular for the management of this reserve [9]. In other words, there is a substantially greater proportion of the benefits accrue to visitors rather than the costs.

\subsection{Result of Multiple Regression}

By using Multiple Linear Regression (MLR) the analysis of the determinant of WTP could be done. The first step was doing classical assumption test. The result showed that the equation model was free from multicollinearity, autocorrelation, and heteroscedasticity problems. The result can be seen at Table 6 .

Table 6. Classical Assumption Test Result

\begin{tabular}{lcc}
\hline 1. Multicollinierity & & \\
\hline \multicolumn{1}{c}{ Independent Variables } & VIF & $\begin{array}{c}\text { Conclusion (passed: } \\
\text { VIF < 10) }\end{array}$ \\
\hline$\left(\mathrm{X}_{1 \mathrm{i}}\right)$ travel cost & 1.691 & passed \\
$\left(\mathrm{X}_{2 \mathrm{i}}\right)$ visitor's age & 1.696 & passed \\
$\left(\mathrm{X}_{3 \mathrm{i}}\right)$ travel distance & 1.243 & passed \\
$\left(\mathrm{X}_{4 \mathrm{i}}\right)$ visitor income & 1.227 & passed \\
$\left(\mathrm{X}_{5 \mathrm{i}}\right)$ visitor assessment & 1.059 & passed \\
\hline
\end{tabular}

2. Heteroscedasticity

\begin{tabular}{lcc}
\hline \multicolumn{1}{c}{ Independent Variables } & Sign. & $\begin{array}{c}\text { Conclusion (passed: } \\
\text { sign. }>0.05)\end{array}$ \\
\hline$\left(\mathrm{X}_{1 \mathrm{i}}\right)$ travel cost & 0.082 & passed \\
$\left(\mathrm{X}_{2 \mathrm{i}}\right)$ visitor's age & 0.104 & passed \\
$\left(\mathrm{X}_{3 \mathrm{i}}\right)$ travel distance & 0.585 & passed \\
$\left(\mathrm{X}_{4 \mathrm{i}}\right)$ visitor income & 0.127 & passed \\
$\left(\mathrm{X}_{5 \mathrm{i}}\right)$ visitor assessment & 0.382 & passed \\
\hline
\end{tabular}

3. Autocorrelation

\begin{tabular}{cccc}
\hline $\begin{array}{c}\text { Durbin-Watson } \\
(\mathrm{DW})\end{array}$ & $\mathrm{dU}$ & 4-dU & $\begin{array}{l}\text { Conclusion (passed: } \\
\mathrm{dU}<\mathrm{DW}<4-\mathrm{dU})\end{array}$ \\
\hline 1.903 & 1.780 & 2.220 & passed \\
\hline
\end{tabular}

Source: Primary data, processed

The result of classical assumption test shows fit model/equation then ready to use for analyzing statistical tests by regression, namely $\mathrm{R}^{2}, \mathrm{~F}$, and $\mathrm{t}$. The regression result can be seen in Table 7 .

Table 7. Regression Result: Statistical Test

\begin{tabular}{lcccr}
\hline \multicolumn{1}{c}{ Independent Variables } & Coeff. & $\mathrm{t}_{\text {stat }}$ & $\mathrm{t}_{\text {table }}$ & $\mathrm{p}$-value \\
\hline$\left(\mathrm{X}_{\mathrm{ii}}\right)$ travel cost & -0.182 & -2.855 & -1.661 & 0.012 \\
$\left(\mathrm{X}_{2 \mathrm{i}}\right)$ visitor's age & -0.017 & -0.122 & -1.661 & 0.787 \\
$\left(\mathrm{X}_{3 \mathrm{i}}\right)$ travel distance & -0.062 & -0.766 & -1.661 & 0.381 \\
$\left(\mathrm{X}_{4 \mathrm{i}}\right)$ visitor income & 0.223 & 2.661 & 1.661 & 0.006 \\
$\left(\mathrm{X}_{5 \mathrm{i}}\right)$ visitor assessment & 0.215 & 2.364 & 1.661 & 0.017 \\
\hline Const. $=1.721$ & & & & \\
$R^{2}=0.354$ & & & & \\
Adj. $R^{2}=0.331$ & & & & \\
$F_{\text {hitung }}=7.315$ & & & & \\
$F_{\text {tabel }}=2.290$ & & & & \\
\hline
\end{tabular}

Source: Primary data, processed

From that result, the equation model can be written as:

$$
\begin{aligned}
\wedge \ln Y_{i}= & 1.921-0.162 \ln X_{1 i}-0.020 \ln X_{2 i}-0.072 \ln X_{3 i}+ \\
& 0.212 \ln X_{4 i}+0.201 \ln X_{5 i}
\end{aligned}
$$

Several points can be explained as follows:

Adj. $\mathrm{R}^{2}$ is 0.331 which means that 33.1 percent all independent variations can explain the dependent variable 
variation, the rest of 66.9 percent is explained by others out of the model. The low Adj.R2 is the common result in terms of cross section data because its characteristic is vary from one individual to another thus the low value is it dosn't matter [19].

$\mathrm{F}$ statistic shows 7.315 which is greater than $\mathrm{F}$ table (2.290) thus it passes the F test. It means that all independent variables in the model have a statistically significant effect on dependent variable (WTP).

The coefficient of $\mathrm{X}_{1 \mathrm{i}}$ is -0.182 shows that the cost of traveling for visitors to Owabong has a statistically significant negative effect ( $\mathrm{p}$-value $=0.012<0.05$ ) on the WTP. It means that if travel cost increases by 1 percent, it will decrease WTP by 0.182 percent, assuming other variables are constant.

The coefficient of $\mathrm{X}_{4 \mathrm{i}}$ is 0.223 , indicating that the individual income of visitors to Owabong has a statistically significant positive effect $(\mathrm{p}$-value $=0.006<0.05)$ on the number of visits to Owabong. In more detail, if the individual income increases by 1 percent, it will also increase WTP by 0.223 percent, assuming other variables are constant.

The coefficient of $\mathrm{X}_{5 \mathrm{i}}$ is 0.215 , indicating that visitor perception of all existing facilities shows a statistically significant positive effect (p-value $0.017<0.05$ ) on the number of visits to Owabong. It means that if visitor perception of facilities tends to be satisfied, it will also increase WTP by 0.215 percent, assuming other variables remain.

The variable having the great effect on WTP is visitor income. This finding can be explained that the higher the visitor income the higher the WTP. In fact, the income is as a dominant variable in making decision of many economic activities, especially consumer behaviour. Nowadays, recreation and travelling are essential consumer behaviour for household. Hence, usually, each household increases the proportion of income for leasure time such as recreation, travelling, hiking, etc.

\section{CONCLUSION}

This research focuses on economics tourism studies which analyze the economic development of three famous tourist destination in Purbalingga Regency, i.e. Owabong Waterpark, Sanggaluri Reptile Park, and Purbasari Riverworld. The objectives of this research are to measure willingness to pay and to analyze its determinant factors of those tourist destinations.

This research findings conclude that: (1) willingness to pay of each destination is still at recommended price/ticket which ranges IDR25,000-35,000 for Owabong Waterpark, IDR15,000-20,000 for Sanggaluri Reptile Park, and IDR20,000-25,000 for Purbasari Riverworld; (2) the major determinant factors of willingness to pay of those three destinations are travel costs, visitor income, and visitor perceptions.

\section{REFERENCES}

[1] Regional Youth, Sport, and Tourism Service of Central Java Province, 2021. Number of International and Domestic Visitors in Jawa Tengah Province, 2014-2020.

[2] Mondino, E. \& Beery, T., 2018. Ecotourism as a Learning Tool for Sustainable Development: the Case of Monviso Transboundary Biosphere Reserve, Italy. Journal of Ecotourism, 18, pp.1-15.

[3] Sondak, C.F.A. \& Chung, I.K., 2015. Potential Blue Carbon from Coastal Ecosystems in the Republic of Korea. Ocean Science Journal, 50(1), pp.1-8.

[4] Wattage P., 2011. Valuation of Ecosystem Services in Coastal Ecosystems: Asian and European Perspectives. Ecosystem Services Economics (ESE) Working Paper Series, No.8. The United Nations Environment Program, Bangkok.

[5] Lisma, N., Yonaldi, S. \& Zulbahri, L., 2016. Faktor-Faktor yang Mempengaruhi Kunjungan Wisatawan ke Objek Wisata Syariah di Sumatera Barat. Jurnal Manajemen dan Kewirausahaan, 8(1), pp.1-15.

[6] Statistics Indonesia, 2019. Indonesia Tourism Contribution to GDP, 2015-2018.

[7] Dinas Pemuda dan Olah Raga dan Pariwisata (Dinporapar) Kabupaten Purbalingga, 2018. Data Pendapatan Objek Wisata. Available at: https://dinporapar.purbalinggakab.go.id/data-pendapatanobyek-wisata/

[8] Jala \& Nandagiri, L., 2015. Evaluation of Economic Value of Pilikula Lake Using Travel Cost and Contingent Valuation Methods. Aquatic Procedia, 4, pp.1315-1321.

[9] Pascoe, S., Doshi, A., Thébaud, O. \& Thomas, C. R., 2014. Estimating the Potential Impact of Entry Fees for Marine Parks on Dive Tourism in South East Asia. Marine Policy, 47, pp.147-152.

[10] Desriani, J., 2017. Nilai Ekonomi Ekowisata Taman Nasional Tesso Nilo dengan Pendekatan Metode Contingent Valuation di Kecamatan Ukui Kabupaten Pelalawan. Journal of Environment and Management Fekon, 4(1), pp.1175-1189.

[11] Dharmawan, A., Subiyanto, S., \& Nugraha, A. L., 2016. Analisis Nilai Ekonomi Kawasan Cagar Budaya Keraton di Kota Cirebon berdasarkan WTP (Willingness to Pay) dengan Pendekatan TCM (Travel Cost Method) dan CVM (Contingent Valuation Method). Jurnal Geodesi Undip, 5(2), pp.25-33.

[12] Zulpikar, F., Prasetyo, D.E., Shelvatis, T.V., Komara, K.K., \& Pramudawardhani, M., 2017. Valuasi Ekonomi Objek Wisata Berbasis Jasa Lingkungan Menggunakan Metode Biaya Perjalanan di Pantai Batu Karas Kabupaten Pangandaran. Journal of Regional and Rural Development Planning, 1(1), pp. 53-63.

[13] Suparmoko, M. \& Ratnaningsih, M., 2016. Ekonomika Lingkungan. Yogyakarta: BPFE.

[14] Bhatt, M. S. and Bath, M.Y., 2016. Valuation of National Parks: An Individual Travel Cost Approach.International 
Journal of Multidisciplinary Research and Development, 3(3), pp.07-12.

[15] Haider, M.Z., Hossain, T., Siddiqui O.I., \& Islam M.S., 2017. Economic Valuation Of The Tourist Spots In Bangladesh. International Journal of Tourism Policy, 8(1), pp.42-64.

[16] Cheung, L.T., \& Jim, C.Y., 2014. Expectations and Willingness to Pay for Ecotourism Services in Hong Kong's Conservation Areas. International Journal of Sustainable and Development World Ecology, 21(2).

[17] El-Bekkay, M., Moukrim, A. \& Benchakroun, F., 2013. An Economic Assessment of the Ramsar Site of Massa (Morocco) with Travel Cost and Contingent Valuation Methods. African Journal of Environmental Science and Technology, 7(6), pp.441-447.

[18] Terry, J., Mukti, A. \& Sunaryati, R., 2020. Valuasi Ekonomi Objek Wisata Dermaga Kereng Bangkirai Sungai Sebangau Kota Palangka Raya. Journal of Environmental and Management, 1(2), pp. 83-90.
[19] Gujarati, D.N. \& Porter, D.C., 2009. Basic Econometrics, 6th ed., New York: The McGraw-Hill Companies, Inc.

[20] Lemeshow, S. \& David, J., 1997. Besar Sampel dalam Penelitian Kesehatan (terjemahan), Yogyakarta: Gadjah Mada University Press.

[21] Hakim, A. R., Subanti, S., \& Tambunan, M., 2011. Economic Valuation of Nature-Based Tourism Object in Rawapening, Indonesia: An Application of Travel Cost and Contingent Valuation Method. Journal of Sustainable Development, 4(2), pp.91-101.

[22] Mojiol, A.R., Guntabid J., Lintangah, W., Ismenyah, M., Kodoh J., Chiang, L.K. \& Sompud, J., 2016. Contribution of Mangrove Forest and Socio-Economic Development of Local Communities in Kudat District, Sabah Malaysia. Internatonal Journal of Agriculture, Foresty and Plantation, 2, pp.123129. 